تبيين ادراك بيماران تحت همودياليز از بيمارى خود: يك مطالعه كيفى

داود حكمت يوץ
رضوان غفارزادَان

مريم سعيدى'

جكيده

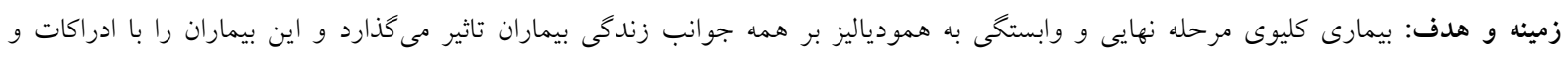

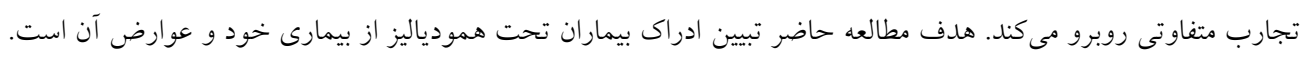

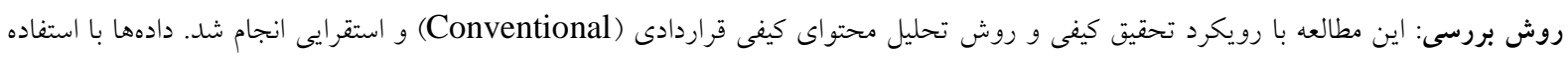

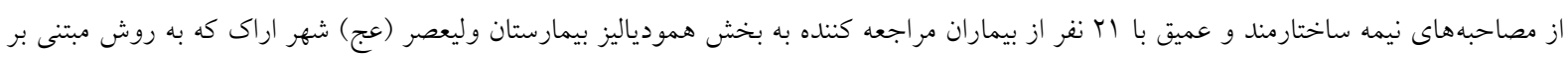

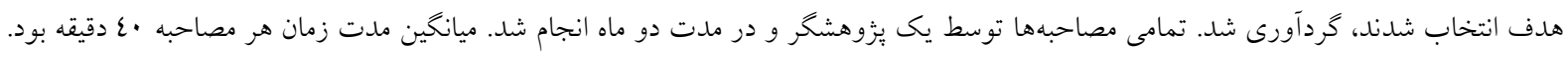

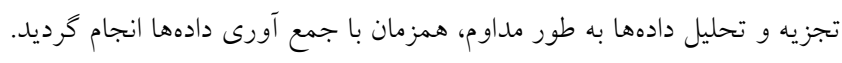

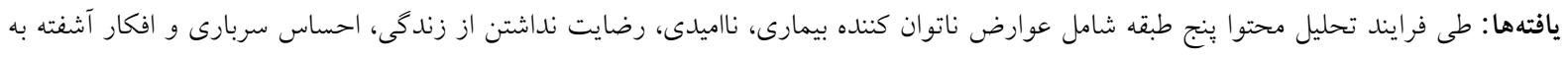

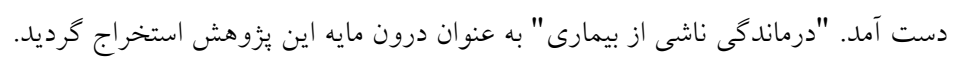

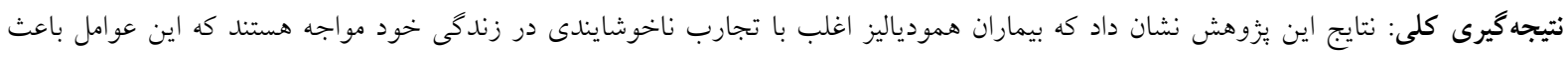

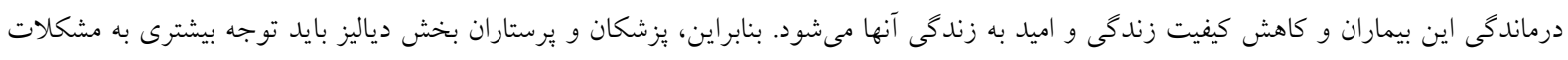

كليد وازهها: بيمارى كليوى مرحله نهايى، ادراك، تحقيق كيفى

تاريخ دريافت: 97/0/1 (5)

تاريخ بذيرش: 97/V/T9

شماره تماس:

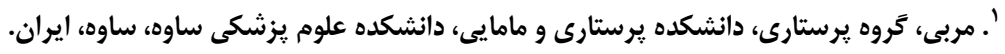

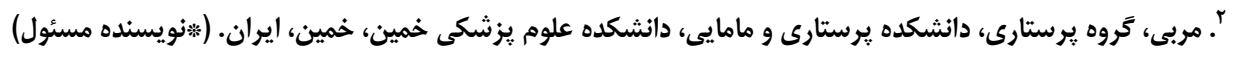


مشاهده مىشود و به طور نامطلوبى بر توانايى افراد

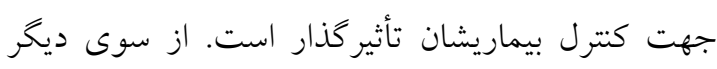

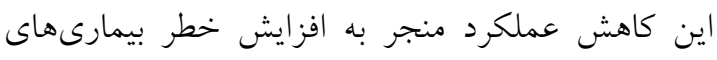

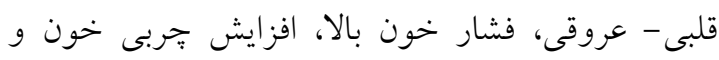

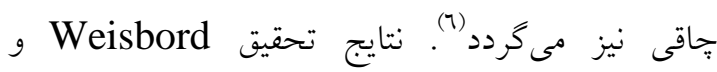

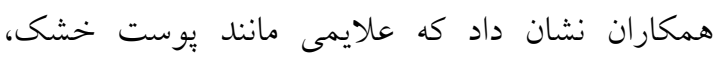
خارش، احساس خستخى و كاهش انرزى، درد مفصلى و

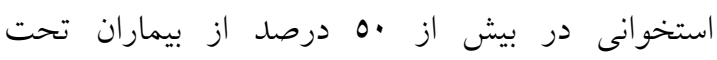

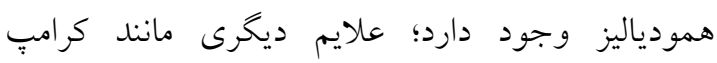

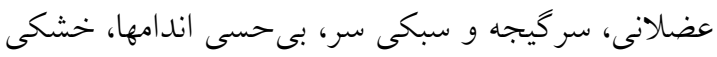
دهان، اختلال خواب و ناتوانى جنسى نيز در بيش از بر ستر

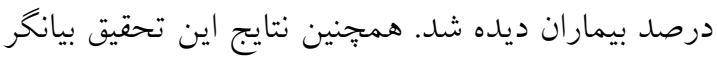

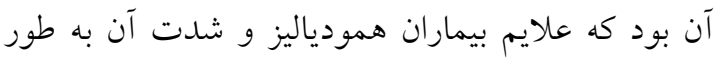
مستقيم با كاهش كيفيت زندكى و افسردگى بيماران ارتباط دارد (V) Yong و همكاران (^) نيز در مطالعه خود خستكى، عدم تحمل سرما، خارش، ضعف اندامهاى تحتانى و مشكل

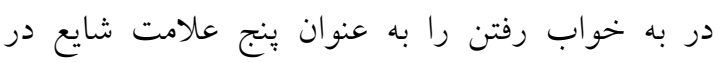

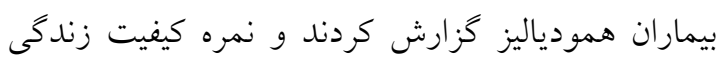

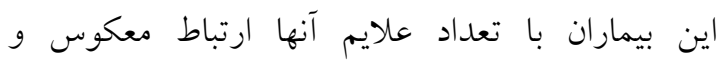

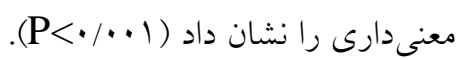
با توجه به اين كه بيماران كليوى مرحله نهايى و تحت داد دان

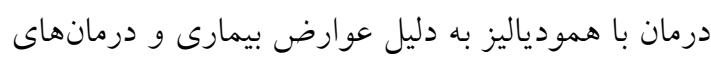

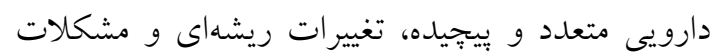

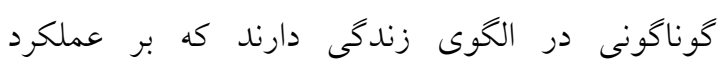

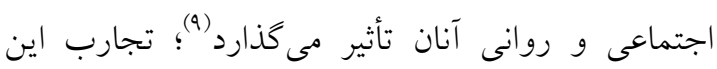

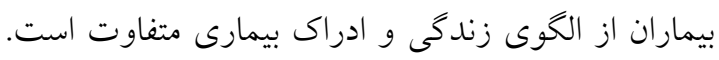

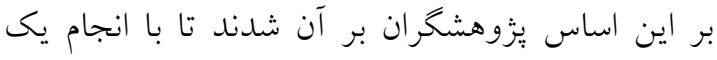
تحقيق كيفى و با طرح اين سوال كه "ادراك بيماران

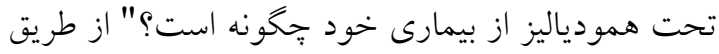

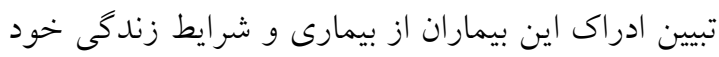

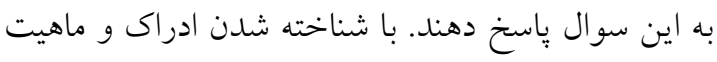

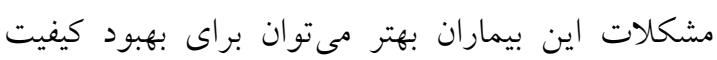

مقدمه بيمارى كليوى مرحله نهايى يك اختلال بيشرونده و

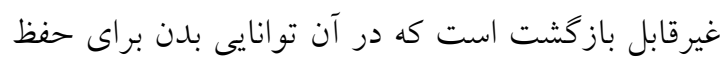

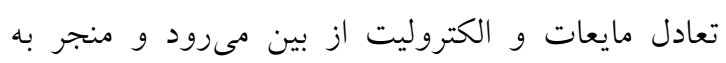
تجمع مواد زائد در بلدن مىشود '(1). دياليز روشى براى خارج ساختن مايعات و فرآوردههاى زائد از بدن است و هنخامى استفاده مىشود كه كليهها نتواندل جنين وظيفهاى را انجام دهند. همودياليز شكل اصلى درمان جايخزين كليه است و بر اساس آمار موجود

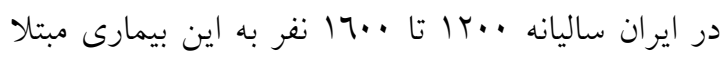

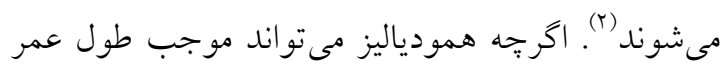
بيمار كردد، اما سير طبيعى بيمارى كليوى را تغيير نداده و به طور كامل جايخزين كاركرد كليوى بيمار نمىشود و بيمار در معرض برخى مشكلات و عوارض قرار مى گيرد. در همودياليز طولانى مدت بيماران هفتهاى دو تا سه جلسه و در هر جلسه به مدت سه تا جهار ساعت تحت همودياليز قرار مى گيرند كه اين مىتواند باعث

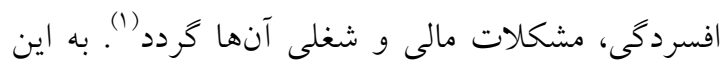
ترتيب، بيماران تحت همودياليز در طيف وسيعى از مشكلات جسمى، روانى، اقتصادى و اجتماعى قرار مى گيرند كه در مجموع كيفيت زندگى آنها را تحت تاثير

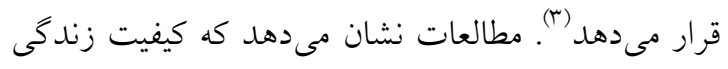
در بيماران تحت همودياليز نسبت به افراد عادى جامعه يايينتر است. عوارض درمان با همودياليز مانند عوارض كوارشى، قلبى عروقى، كم خونى، عوارض عصبى و... كيفيت زندگى بيماران را بر هم زده و باعث افسردگى و كاهى خودكشى در آنان مى گردد (ع). افسردگى در بيماران تحت همودياليز از شايعترين مشكلات روانشناختى مىباشد و يكى از مهمترين عو امل بيش بينى كننده نتيجه درمانى و بقاى اين بيماران است. در بيماران تحت

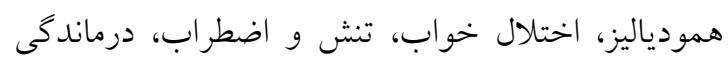
آموخته شده و احساس عدم كنترل بر سلامت خود احتئ بسيار شايع است (0) كاهش جشمخير فعاليت فيزيكى از از جمله مشكلاتى است كه به وفور در بيماران همودياليز 
زير آغاز مىشد: از اين كه به بيمارى كليوى مرحله

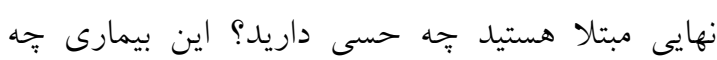

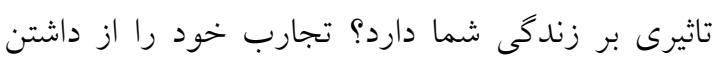

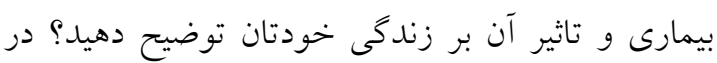

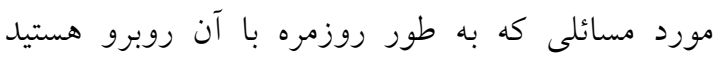
توضيح دهيد. سبس سوالات بعدى براى ادامه و كامل شدن مصاحبه و دست يابى به دادههاى غنىتر بر اساس

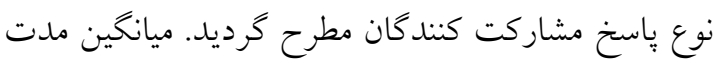

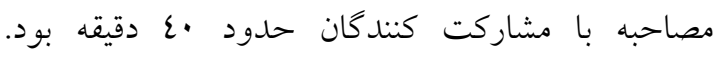

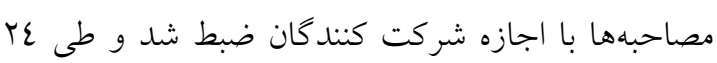

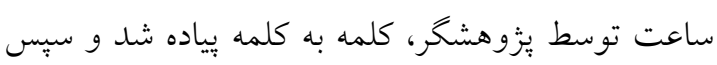

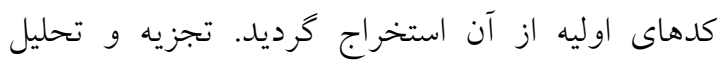

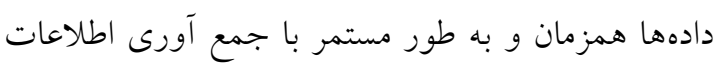

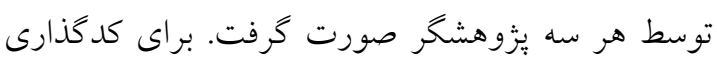

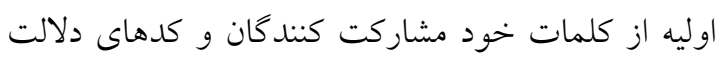

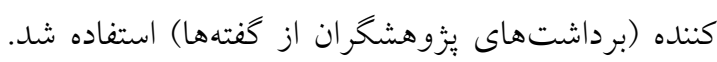
سبس مصاحبههاى بعدى انجام كرفت. اشباع دادهها از

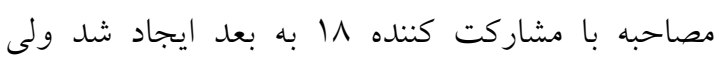

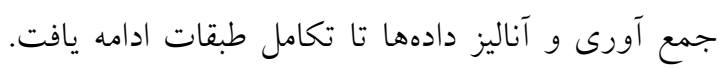

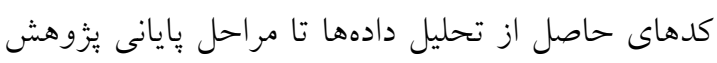

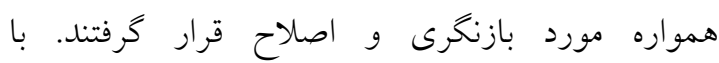

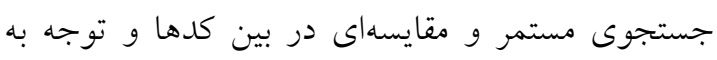

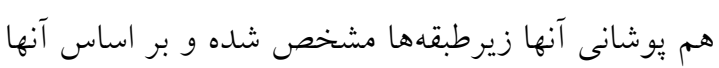

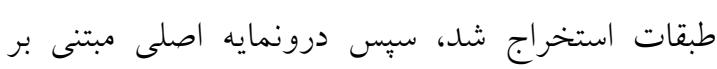

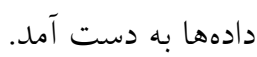

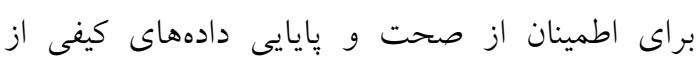
معيارهاى دقت علمى مانند اعتبار (Credibility)، قابليت اعتماد يا حسابرسى (Dependability)، قابليت

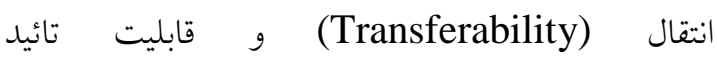
Lincoln guba (Confirmability) شل شل روشهاى تعيين اعتبار در اين يزّوهش شامل دركيرى طولانى مدت محقق با موضوع تحقيق و دادهها، كنترل

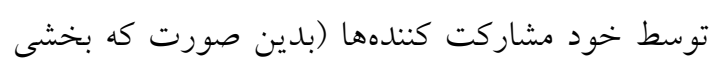

زندكى و كاهش مشكلات آنها اقدامات درمانى و آموزشى را برنامه ريزى و اجرا نمود.

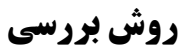

با توجه به سوال يزوهش و و ماهيت موضوع، در اين

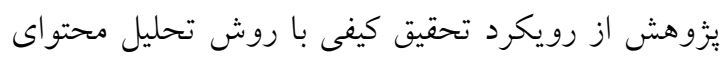
كيفى قراردادى (Conventional) و استقر ايى استفاده

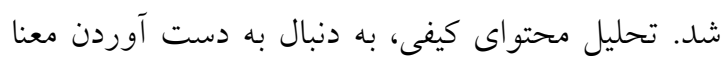

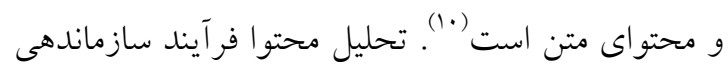

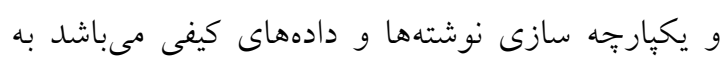

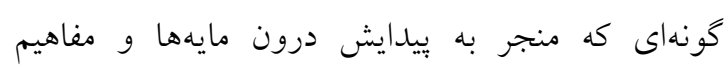
مىشود" ". در اين روش، پِ يس از مشخص كردن واحد

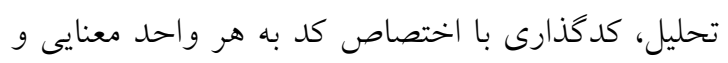

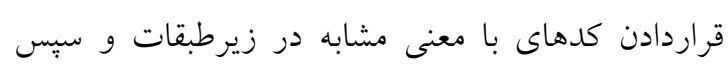

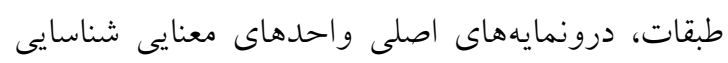

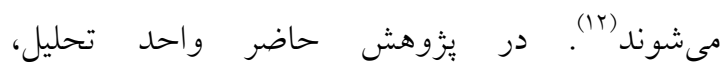
مصاحبه هاى انجام گرفته با بيماران تحت همودياليز بود.

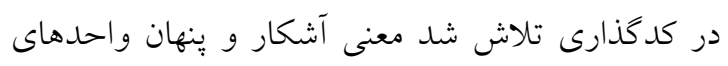

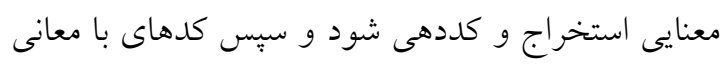

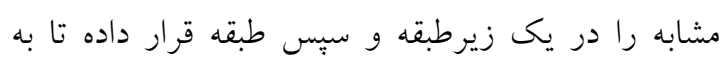

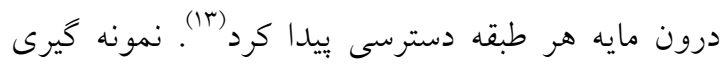

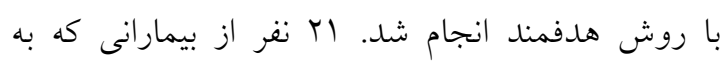

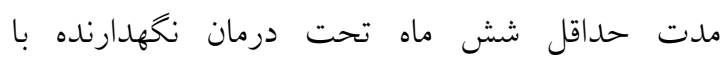

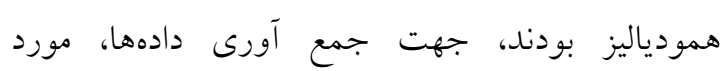
مصاحبه قرار كرفتند. مصاحبهها در بخش هموديز هودياليز

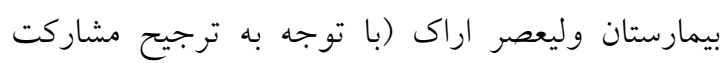

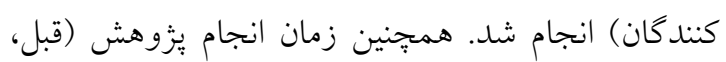

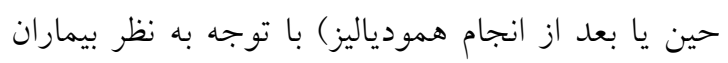

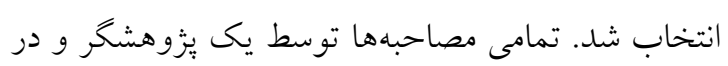

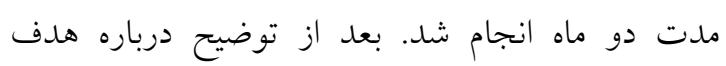

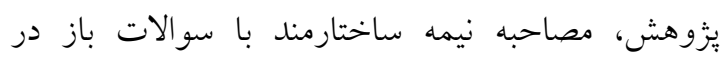

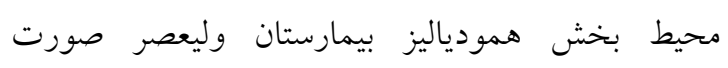

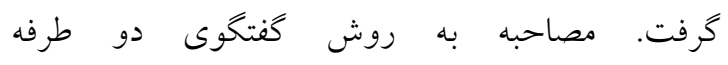
با سوالاتى نظير سوالات (Conversational style) 
داده شد تا در هر مرحله از ئزوهش بر حسب صلاحديد خود از مطالعه خارج شوند.

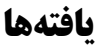

در اين يزٔوهش اب نفر از بيماران تحت همودياليز مورد مصاحبه قرار كرفتند. ميانگين سنى مشاركت كنندگان س 10/10/19 10/ بود. كمترين و بيشترين سن مشاركت كنندگان به ترتيب TV و 70 سال بود. سابقه بيمارى كليوى در مشاركت كنندگان به طور ميانگين سبر سال بود. سابقه همودياليز نيز به طور ميانكين V/T 2/17

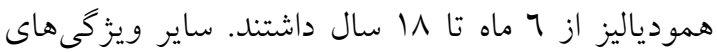
جمعيت شناختى بيماران شركت كننده در جدول شماره ا خلاصه شده است.

جدول شماره ا: مشخصات جمعيت شناختى بيماران

\begin{tabular}{|c|c|c|}
\hline فراوانى (درصد) & طبقه بندى & متغيرها \\
\hline$(0 V / \backslash \varepsilon) I r$ & زن & جنسيت \\
\hline$\left(\sum Y / \wedge T\right) q$ & 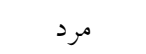 & \\
\hline$(77 / V) \mid \varepsilon$ & متاهل & وضعيت \\
\hline$(\Gamma / \Gamma) V$ & مجرد & تاهل \\
\hline$(\Gamma / \Gamma) V$ & بي سواد & \\
\hline$(19 / \cdot 0) \varepsilon$ & ابتدايى & تحصيلات \\
\hline$(\varepsilon / V\urcorner))$ & راهنمايى & \\
\hline$\left(\sum \Gamma / \wedge T\right) q$ & متوسطه & \\
\hline$(O V / I \varepsilon) I T$ & خانه دار & \\
\hline$(9 / 0 Y) Y$ & كارمند & \\
\hline$(\varepsilon / \vee\urcorner) 1$ & كارگر & شغل \\
\hline$(1 \varepsilon / r \Lambda) r$ & بازنشسته & \\
\hline$(1 \varepsilon / \Gamma \Lambda) r$ & بيكار & \\
\hline
\end{tabular}

دادههاى بلدست آمده از مصاحبه با بيماران تحت همودياليز در اين مطالعه، بيانخر ادراك بيماران از بيمارى خود و تجارب آنان است كه به روش علمى بر كرفته از تحقيقات كيفى بيان مىشوند. در تجزيه و تحليل مداوم دادهها، تعداد •^^ كد اوليه استخراج شد كه با در نظر كرفتن هميوشانى و ادغام آنها، تعداد آنها به
از متن مصاحبه همراه با كدهاى اوليه به رؤيت مشاركت كنندكان رسيد و ميزان تجانس كدهاى استخراج شده محقق از دادهها با نظر مشاركت كنند گان مقايسه كرديد و در صورت نياز تغييرات لازم داده شد). تلفيق دادهها (به صورت مصاحبه با بيماران در زمانهاى مختلف و ولف شيفتهاى مختلف دياليز) و نمونه كيرى با حداكثر تنوع (انتخاب مشاركت كنندكان از بين بيماران مختلف از لحاظ سن، جنس، سطوح فرهنگى، اقتصادى و اجتماعى و...) انجام شد. همجنين تأييديذيرى يافتهها با كنترل توسط ناظران خارجى آشنا به تحقيق كيفى سنجيده شد، به اين معنى كه بخشهايى از متن مصاحبه به همراه كدهاى مربوط و طبقات يديدار شده توسط دو ناظر آشنا

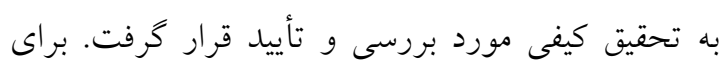
حسابرسى تحقيق، محقق مراحل و روند تحقيق را به طور دقيق ثبت و گزارش نمود تا امكان بيخيرى تحقيق براى ديخران فراهم شود. جهت انتقال يذيرى يافتها سعى شد نقل قولهاى مشاركت كنندگان به همان صورتى كه گفته شد، ارايه گردد. همجنين ويزّكى هاى

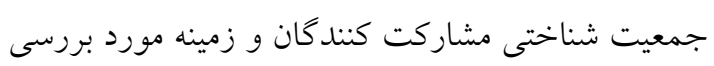
با جزييات بيان كرديد تا خو اننده يزوهش بتواند در مورد استفاده از نتايج مطالعه تصميم گيرى كند. به منظور رعايت ملاحظات اخلاقى، مجوز كميته اخلاق دانشخاه علوم يزشكى اراى براى انجام يزوهش گرفته

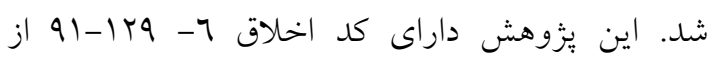
كميته اخلاق در بزوهش دانشخاه علوم يزشكى اراى مىباشد. يزوهشخر علاوه بر معرفى خود و بيان اهداف يزوهش، از مشاركت كنند كان خواست تا رضايت نامه آكاهانه شركت در بززوهش را تكميل كنند و بيش از شروع مصاحبه، اجازه ضبط صدا و يادداشت بردارى از آنها گرفته شد. به مشاركت كنند كان اطمينان داده شد كه در هنخام انتشار نتايج، همه اطلاعات فردى محرمانه باقى خواهد ماند و يس از گزارش نهايى، فايلهاى صوتى حذف خواهند شد. به مشاركت كنندگان اجازه 
"درماندگى ناشى از بيمارى" به عنوان درون مايه اصلى

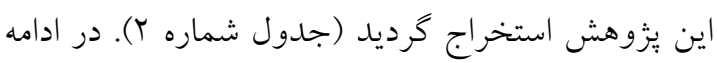

به توصيف و تبيين طبقات يرداخته مىشود.
تقليل يافت. طى فرايند تحليل محتوا ينج طبقه شامل

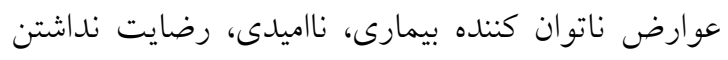

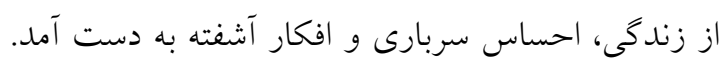

جدول شماره r: زيرطبقات، طبقات و درون مايه به دست آمده از مصاحبه با بيماران همودياليز مشاركت كننده در يزوهش

\begin{tabular}{|c|c|c|}
\hline درون مايه & طبقات & زير طبقات \\
\hline \multirow{5}{*}{ 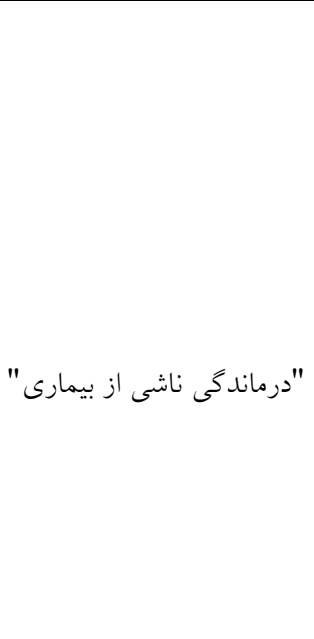 } & عوارض ناتوان كننده بيمارى & 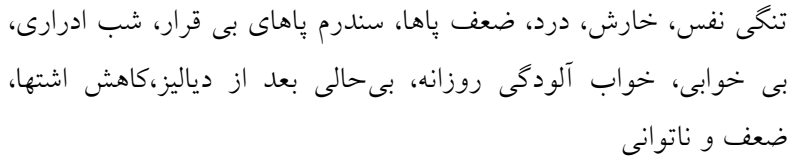 \\
\hline & 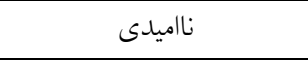 & احساس يوجى، ناميدى، آرزوى مرگ، بى حوصله بودن، احساس افسردگى \\
\hline & 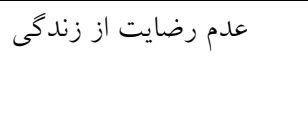 & 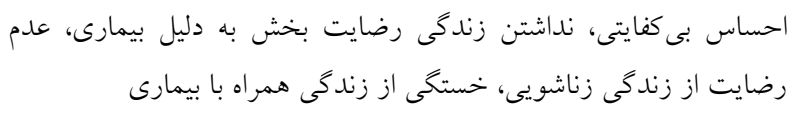 \\
\hline & 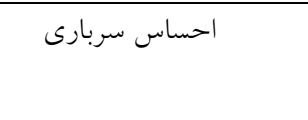 & احساس وابستخى به ديخران، احساس شرم به دليل وابستخى، احساس به دليل \\
\hline & افكار آشفته & 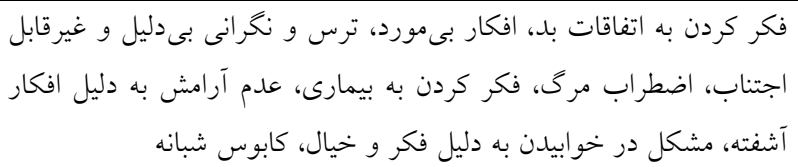 \\
\hline
\end{tabular}

در رختخواب مىنشينم و در حاليكه برقها خاموش /ست و بقيه خواب هستند، من بيدارم.... كاهى اوقات به خودم مى آيم و مىبينم ساعت ع صبح شله است و من همحِنان در رختخواب نشسته/م".

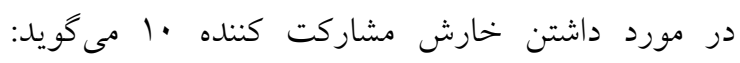
"بيشتر وقتها خارش دارم، خيلى بلنم مى خارد، آنتلدر

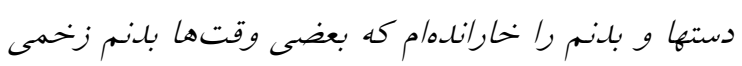
و خراشيله شله است، خلاصه خارش خيلى اذيتم مى كنل ". ناميدى در اين يززوهش، اغلب بيماران همودياليز با نوعى احساس ناميدى مواجه بودند و اين احساس در صحبتهاى آنها موج مىزد. آنها بيان كردند كه اميدى به آينده ندارند، تمايل به تنهايى و كريه دارند، ميل و رغبتى براى انجام كارها ندارند و روحيهشان ضعيف شده است. برخى از مشاركت كنندگان بيان كردند كه به دليل بيمارى و مشكالاتى كه دارند، آرزوى مرگ مى كنند.
عوارض ناتوان كننده بيمارى بسيارى از مشاركت كنندكان از مشكلات ناتوان كننده ناشى از بيمارى شامل درد به خصوص درد پيا و كمر، خارش، تنكى نفس، كاهش اشتها، بى حالى بعد از دياليز، بى خوابى، مور مور شدن ياها هنخام خواب (سندرم ياهاى

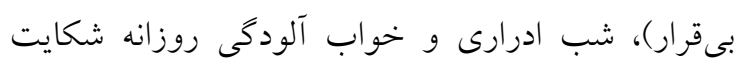
داشتند. در واقع هر يك از مشاركت كنندگان دجّار يك يا جند عارضه از عوارض مذكور بودند و اين مشكل باعث افت كيفيت زندكى آنها شده بود. در اين رابطه مشاركت كننده شماره يك مى گويد: "از زمانى كه كليههايم را از دست دادهام خيلى بيمارم، دست ها و وِاهايم درد مىكند، نفسم تنكى مى كند، وقتى هم كه دياليز مىشوم، بدتر مىشوم، بى حال مىشوم؛ بدنم قوت ندارد...". برخى از بيماران همودياليز شركت كننده در اين بزوهش بـ اظهار داشتند كه دجار اختلال در خواب هستند و خواب خوبى ندارند. در اين رابطه مشاركت كننده شماره هفت مى گويد: "من اصلًا شبها خوابم نمسبرد، وقتى به رختخواب مىروم هر كارى مىكنم خولبم نمىبرد، همش 
در مورد عدم رضايت از زندكى مشاركت كننده شماره

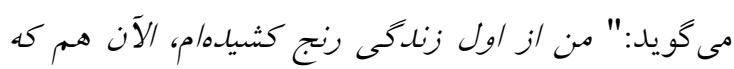

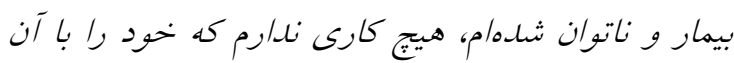

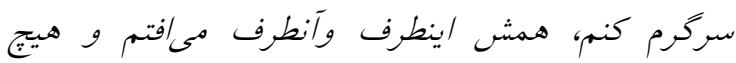

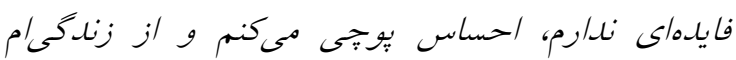

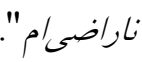
مشاركت كننده شماره نه مى گويد: "از اين وضعيت خسته شده/م، نه كارى دارم كه انجام بلدهم، نه تغريحى د/رم، نه جايى مىروم، همش در خانه نشسته/م، نه خواب خوبيى دارم، نه اشتهايى دارم كه بتوانم جيزى بخورم، خيلى

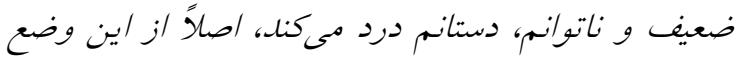

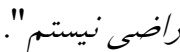
مشاركت كننده شماره 11 مى گويد: "به دليل شرايط و مشكلاتى كه دارم، نمىتوانم نيازهاى همسرم را برآورده نمايم و به همين دليل با همسرم اختلاف بيدا كردم".

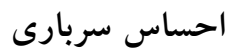
در اين يزوهش اغلب بيماران همودياليز بيان كردند به

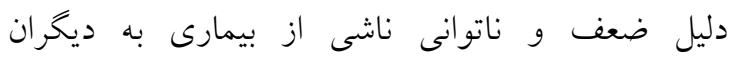

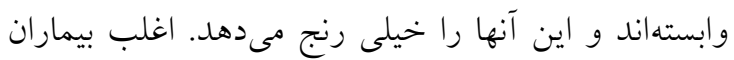
بيان كردند كه براى انجام كارهاى روزانه خود، كارهاى منزل، خريد، بيرون رفتن و... نياز به كمك ديخران دارند و از اينكه براى انجام اين كارها به ديخران وابستهاند، احساس شرم و احساس سربارى داشتند. در اين رابطه، مشاركت كننده شماره 10 مى گويد: "هميشه به كمك دخترم نياز دارم، /ز بلدن خود واماندهام

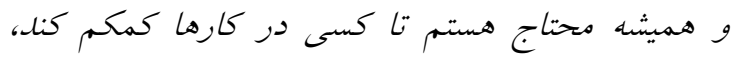

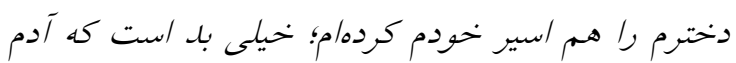

$$
\text { محتاج و سربار كسى باشد ". }
$$

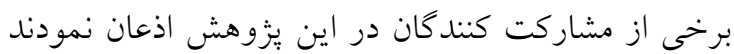

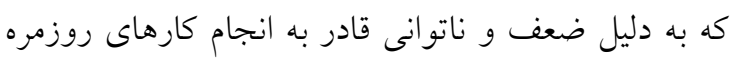

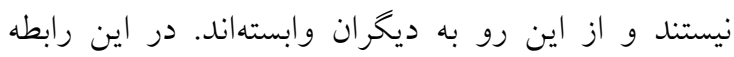

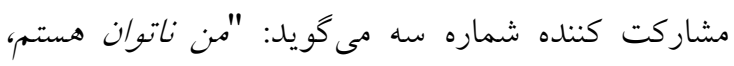
بيشتر /وقات ضعف دارم.... تنهايى نمىتوانم كارى انجام

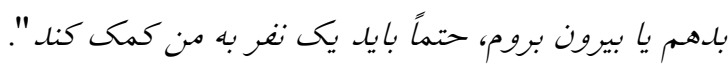

در اين باره مشاركت كننده هشت مى كويد: "بعضى

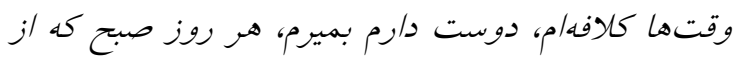

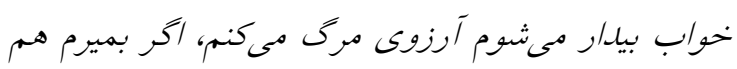

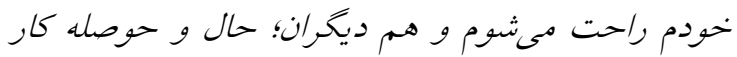

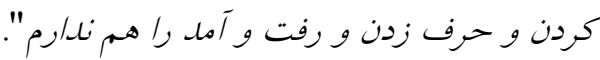

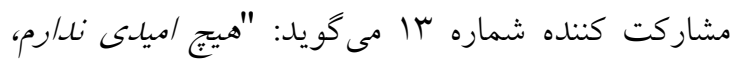

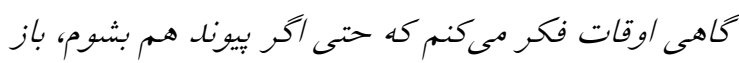

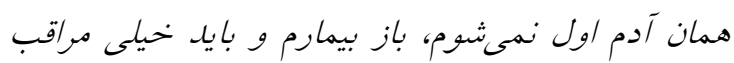
باشم؛ حتى شايد باور نكنيد كاهى اوقات هنغام دياليز

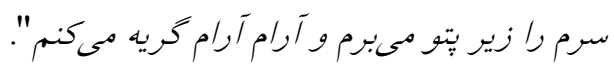

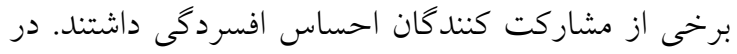
اين رابطه مشاركت كننده شماره جِهار مى كويد: "معنولًا

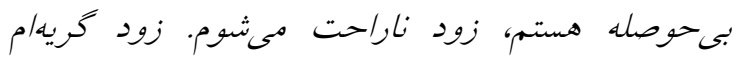

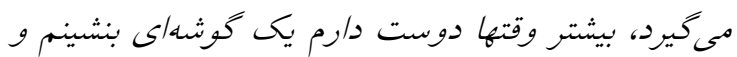

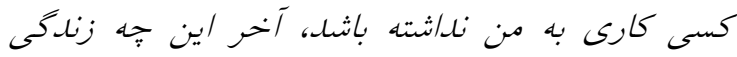
است... جه مىشود كرد، سرنوشت ما هم همين بوده است " مشاركت كننده شماره 17 مى گويد: "همش دوست دارم

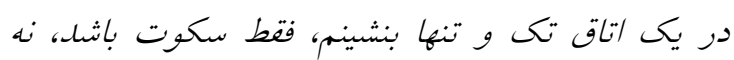

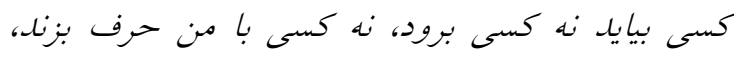

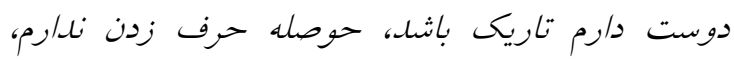
خيلى وقتها براى خودم آواز مىخوانم، خيلى وقتها

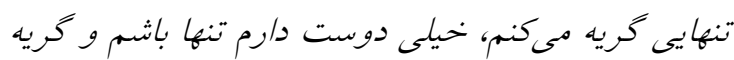

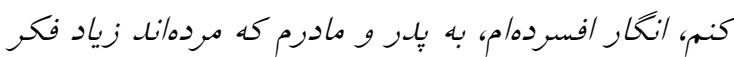
مىكنم، دركل خيلى بيى حوصلهام".

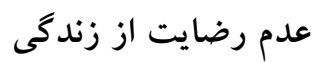
در اين يُزوهش اغلب مشاركت كنندگان بيان كردند كه از زندگى خود راضى نيستند. آنها از شرايط خود ناراحت بودند و از اين كه نمىتوانند مانند ديخران زندگى كنند،

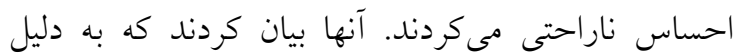

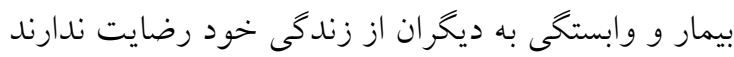
و از اين شرايط خسته شدهاند؛ احساس بى كفايتى مى كنند

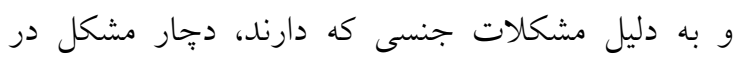

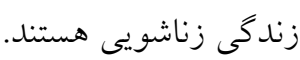


مى گويد: "بيشتر اوقات فكر مىكنم، به همه جيز فكر

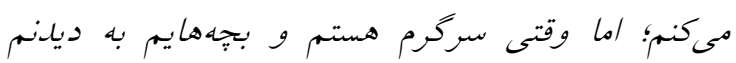

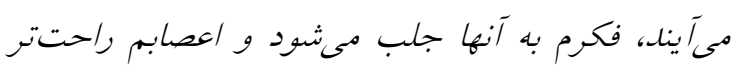

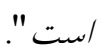
برخى از بيماران بيان كردند كه به اتفاقات بد احتمالى، به

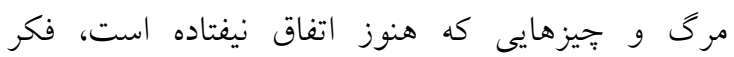
مى كنند. در اين رابطه مشاركت كننده شماره هامئى هويلد:

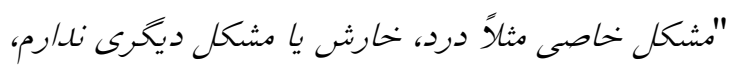
فقط استرس دارم، استرس اتغاقهايي كه افتاده و نيفتاده،

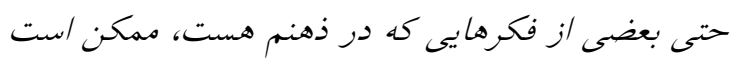

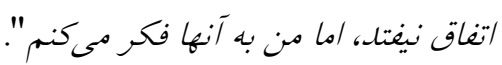

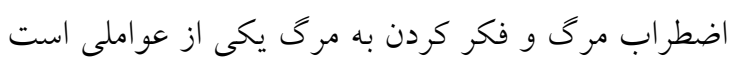

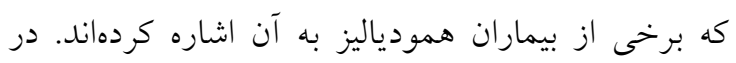

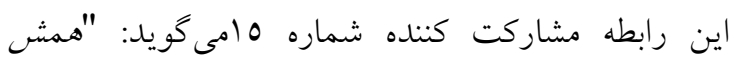

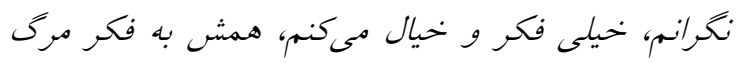
هستم، همش احساس مىكنم مىميرم. هزاران فكر و

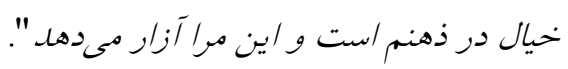

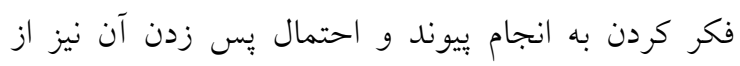

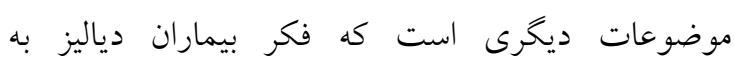

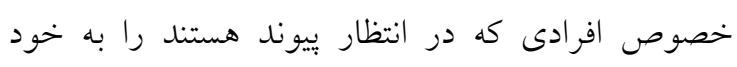
مشغول مى كند. در اين رابطه مشاركت كننده شماره عادئ

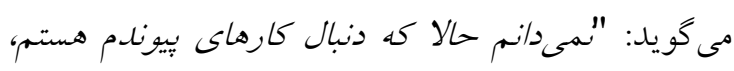

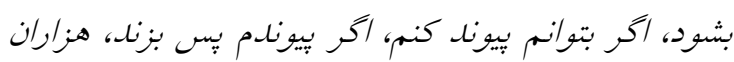

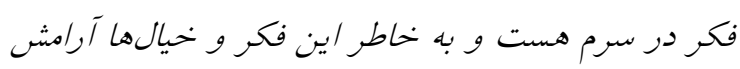

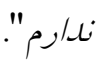

\section{بحث و نتيجه كيرى}

نتايج اين يزوهش نشان ديجهيرى داد كه بيماران همودياليز به دليل

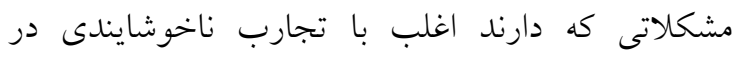

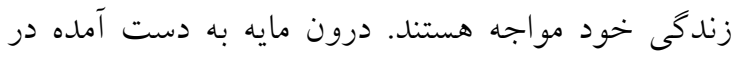
اين يزوهش درماندگى ناشى از بيمارى بود. يافتههاى اين

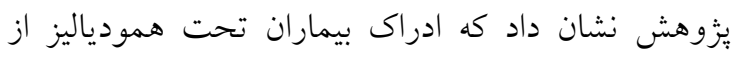

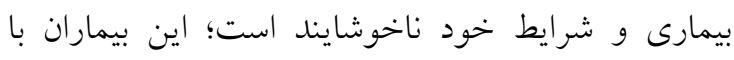
عوارض بسيارى ناشى از اختلال در عملكرد كليه و درمان
برخى از مشاركت كنند كان از اينكه به ديخران وابستهاند احساس شرم داشتند. در اين رابطه مشاركت كننده شماره

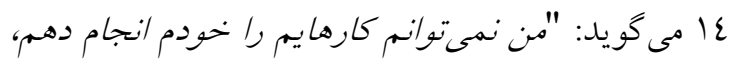

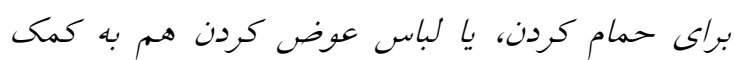

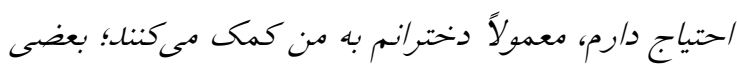
وقتها خجالت مىكشم و فكر مىكنم اكر نبودم بهتر

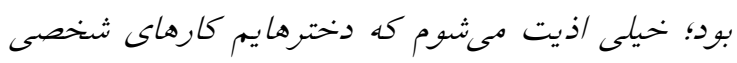

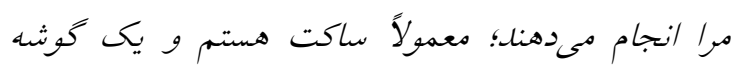
نشسته/م و به در و ديو/ر نغاه مىكنم، خيلى ناتوانم و

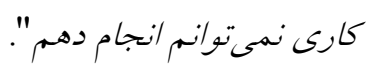
افكار آشفته بيشتر بيماران همودياليز بيان كردند كه به دليل شرايطى كه أتهنه

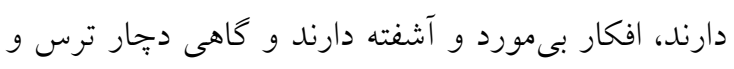

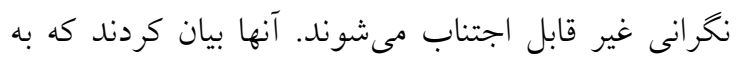

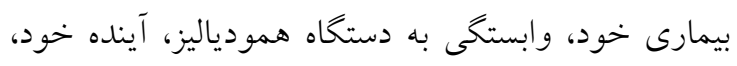

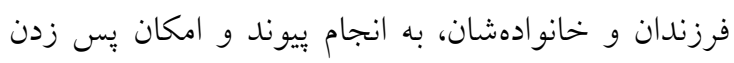

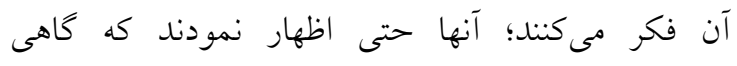
بخصوص قبل از خواب به اتفاقات بد و اتفاقاتى كه هنوز

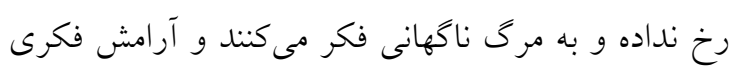
ندارند. IV درباره داشتن افكار آشفته مشاركت كننده شماره

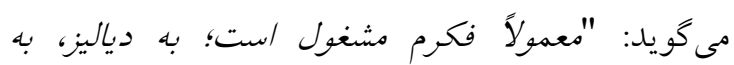

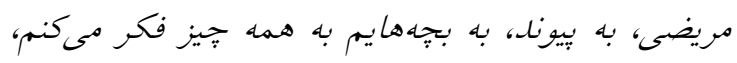

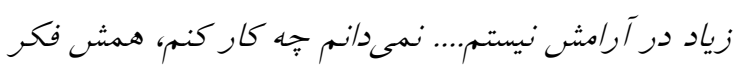
و خيال مىكنم". مشاركت كننده شماره سا مى كو يد: "معنولاً فكرم مشغول

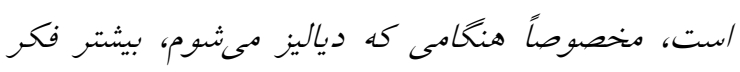

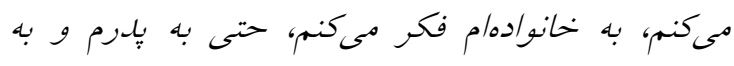

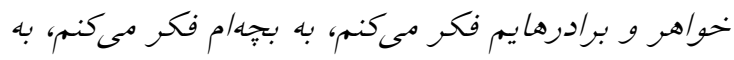

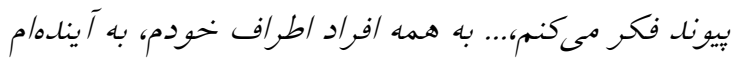
فكر مىكنم، ذهنم مشغول /ست، خيلى فكى آرامى ندارم".

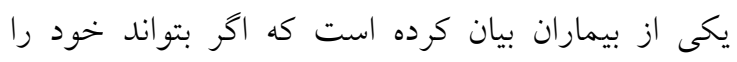

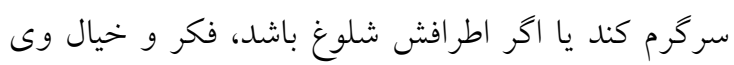

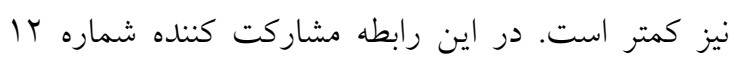


همكاران(1) كه يك مطالعه كيفى با هدف تبيين معناى

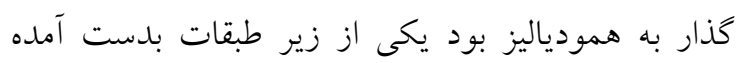

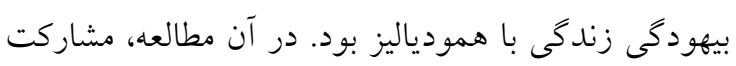

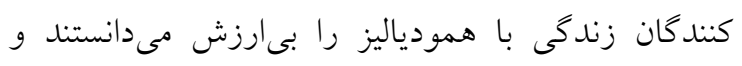

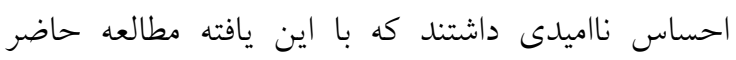

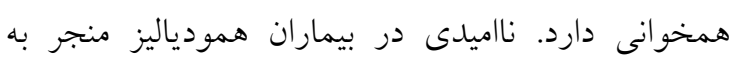

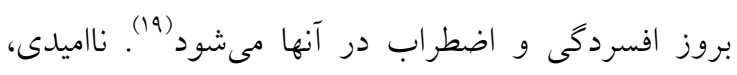

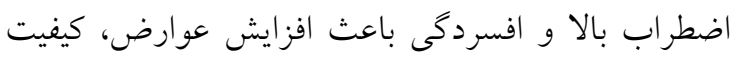

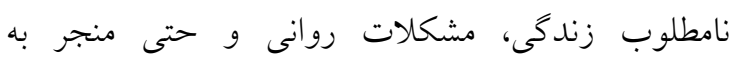

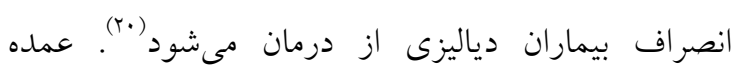

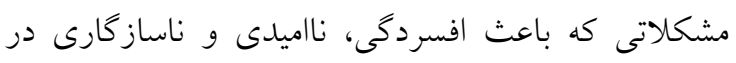

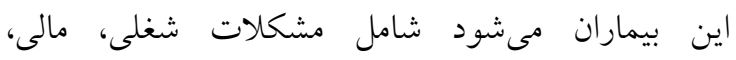

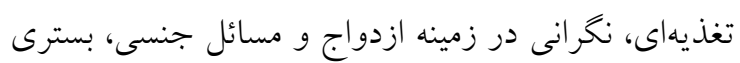
شدن مكرر و ترس از مرك مىباشد (II).

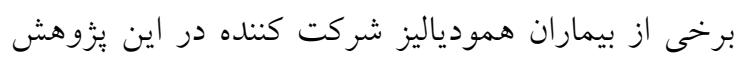

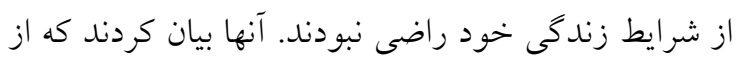

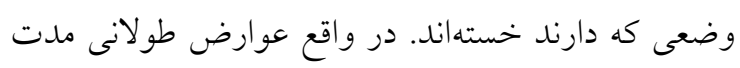
بيمارى منجر به عدم رضايت از زندكى در در اين بيماران

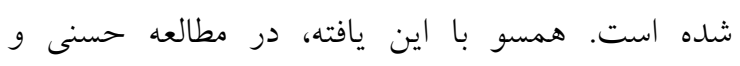

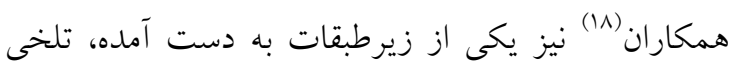

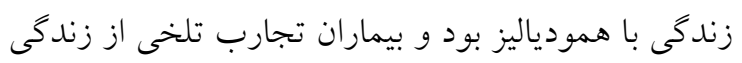

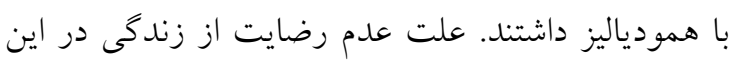

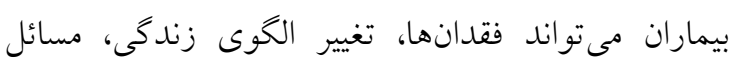

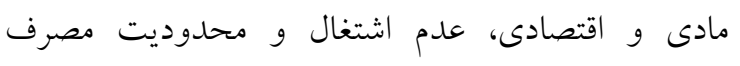

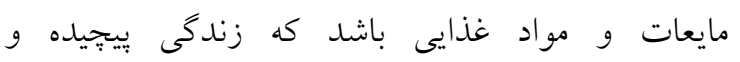
تغيير يافتهاى را به بيمار و خانواده او تحميل مى كند (17).

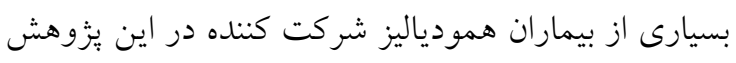

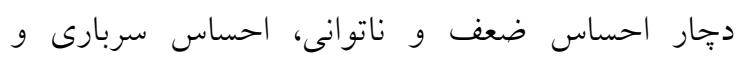

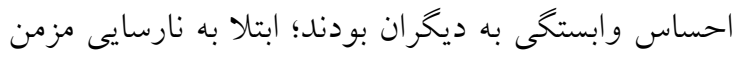

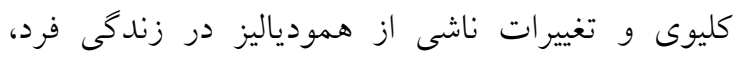

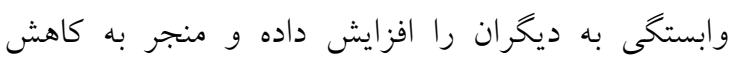

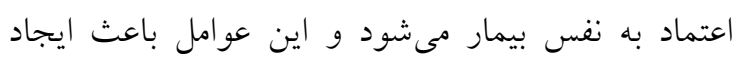

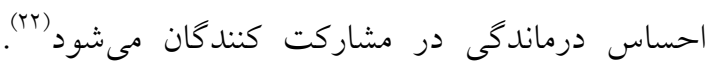
مطالعات نشان دادهاند كه بيماران تحت درمان دران بان همودياليز
با همودياليز مواجه هستند كه اين عوارض به شدت

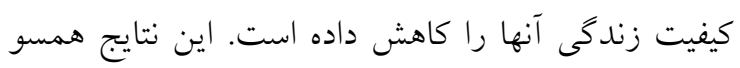

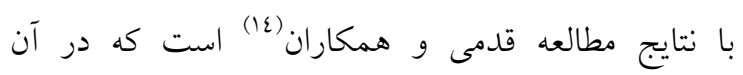
مشاركت كنندكان تجارب خود را از انجا انجام همودياليز بسيار ناخوشايند و طاقت فرسا توصيف كرده بودند. يافتهاى حاصل از اين بُزوهش نشان داد كه بيماران

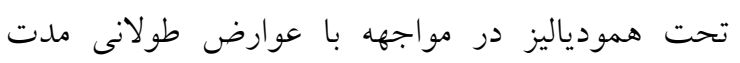

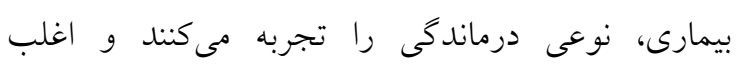
مجبورند با درجاتى از وابستخى به ديخران مدارا نمايند.

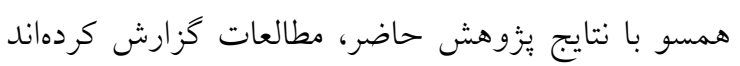

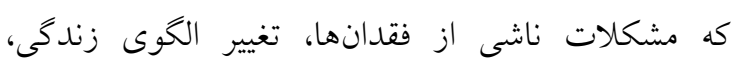

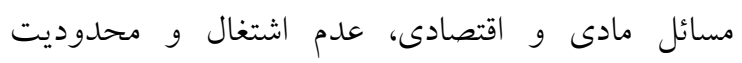

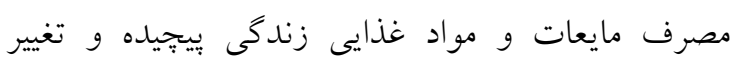

يافتهاى را به بيمار و خانواده او تحميل مى كنند (10.17).

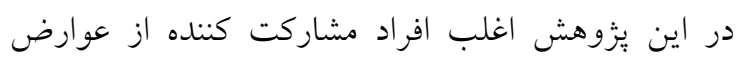

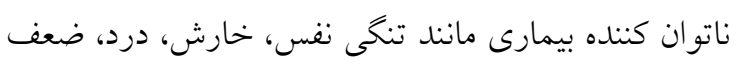

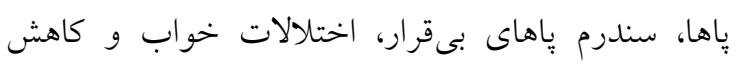

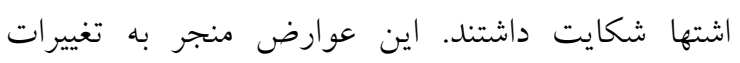
جشمخيرى در زندگى اين بيماران شده بود. همسو با اين إنس

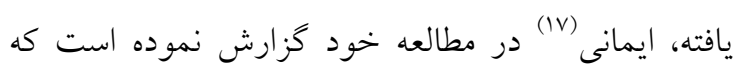
عوارض عمده بيمارى كليوى مرحله نهايى به ترتيب

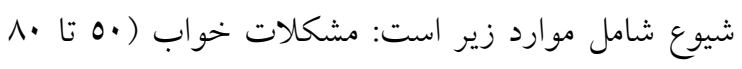

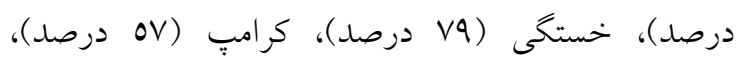

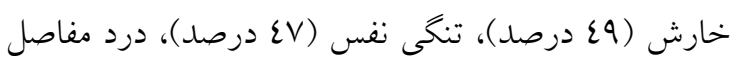

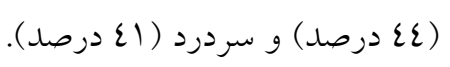
علاوه بر عوارض جسمى ناشى از بيمارى، مشكلات

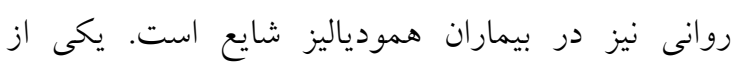

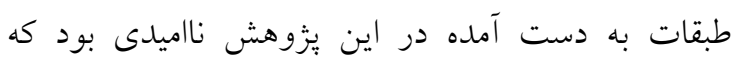

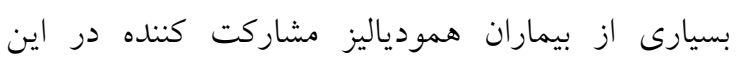

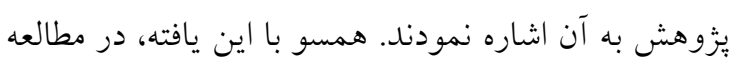

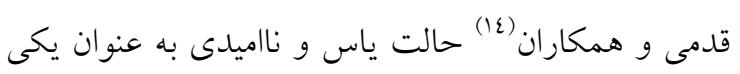

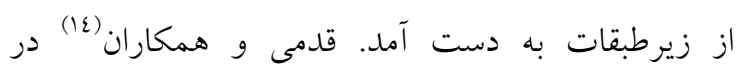
يافتهاى مطالعه خود گزارش كردند كه بيماران همودياليز

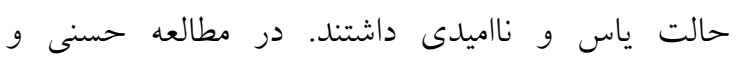


يكى از محدوديتهاى اين يزوهش آن بود كه مشاركت

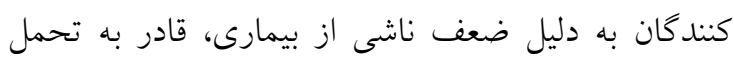

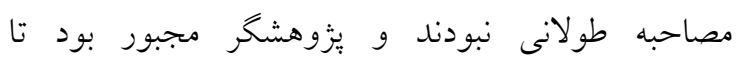

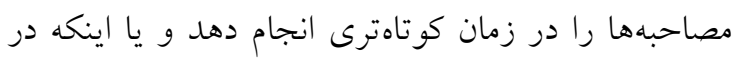
بين مصاحبهها وقفهاى براى استراحت مشاركت كنندگان اختصاص دهد. - مهن. نتايج اين يزوهش نشان داد كه بيماران تحت همودياليز

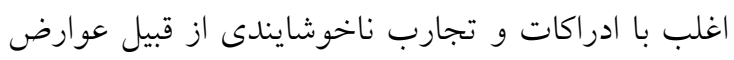

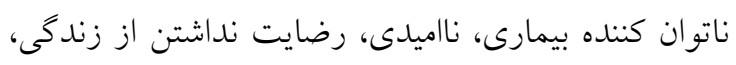
احساس ضعف و ناتوانى، احساس سربارى و افكار

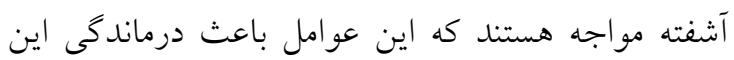

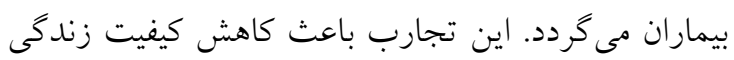

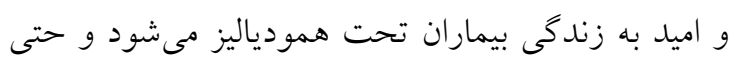

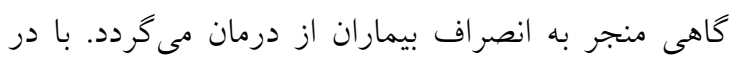

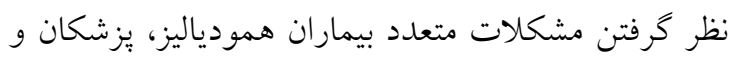

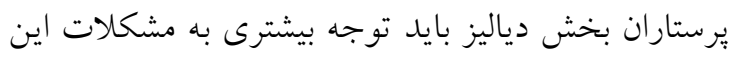

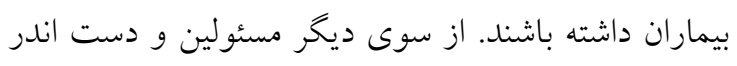
كاران سلامت بايد توجه بيشترى به اين بيماران داشته دانه

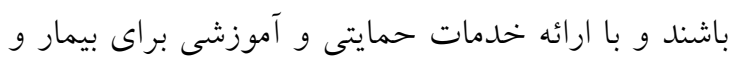

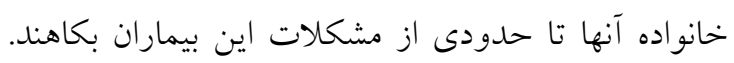

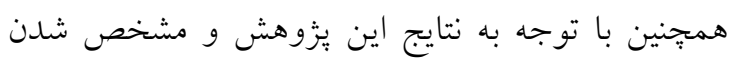

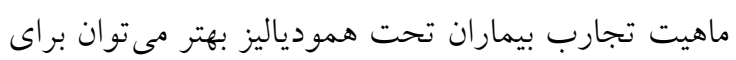
كاهش مشكلات و بهبود كيفيت زندگى آنها اقدامات درمانى و آموزشى را برنامه ريزى و اجرا نمود.

\section{تقدير و تشكر}

اين يزوهش بركرفته از طرح مصوب دانشكده برستارى و

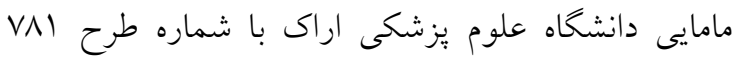

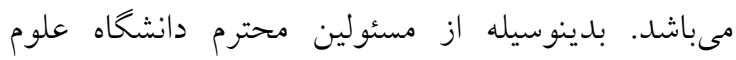

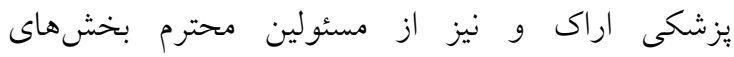

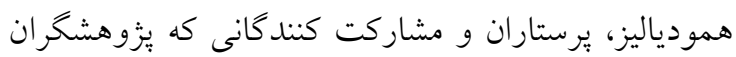

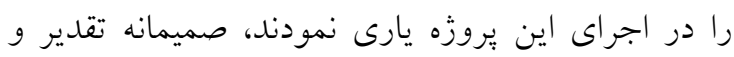

$$
\text { تشكر مى كردد. }
$$

حدود 0 درصد كاهش ظرفيت كار جسمانى را در

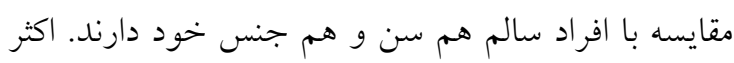
بيماران همودياليزى داراى سبك زندكى غير فعال مى باشند

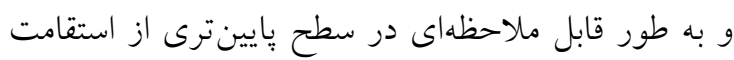

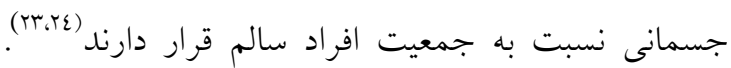

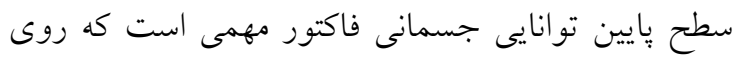

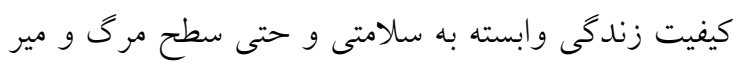

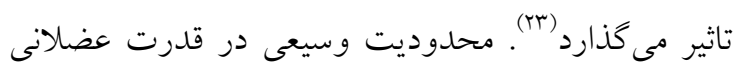

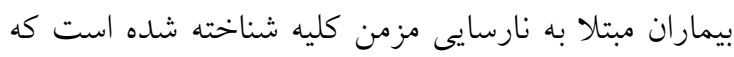

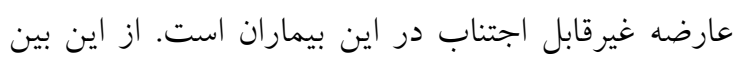

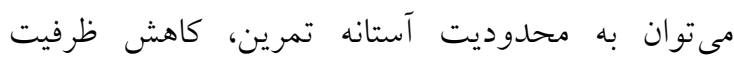

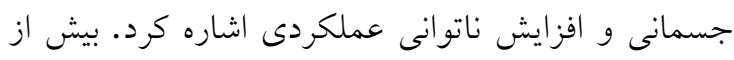

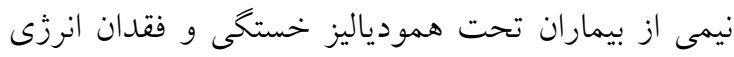

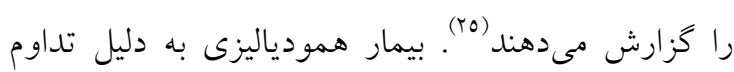

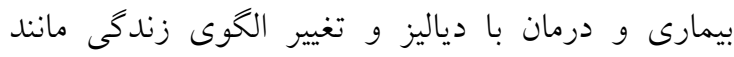

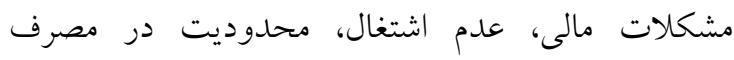

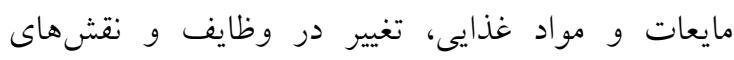
خانوادگى و كاهش توانايى در انجام اهداف طولانى مدات

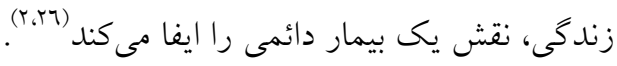

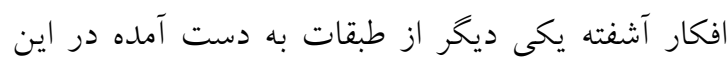

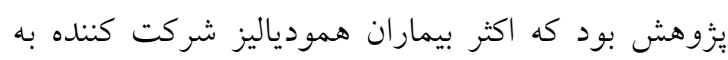

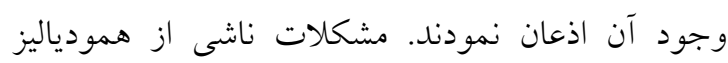
تنشزا مىباشد و باعث بروز افكار آشفته در بيمار

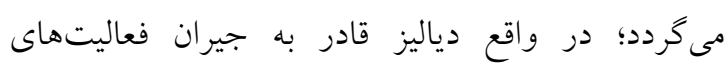
متابوليكى از دست رفته نيست كه اين خود دئ ديك عاليز

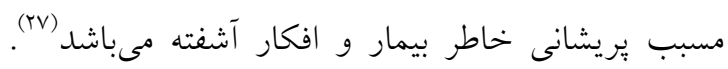
بيماران تحت درمان با همودياليز علاوه بر مشكلات

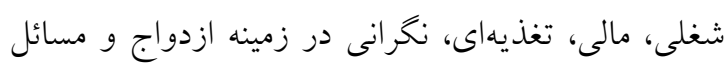
جنسى و بسترى شدن مكرر به دليل شرايط استرس آور

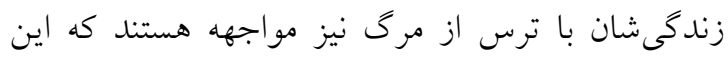
عوامل منجر به بروز افكار آشفته در اين بيماران

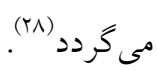


1- $\quad$ Hinkle JL, Cheever KH. Brunner \& Suddarth's textbook of medical-surgical nursing: $13^{\text {th }}$ ed Lippincott Williams \& Wilkins; 2013. Philadelphia: Lippincott.

2- $\quad$ Alidosti M, Hemati Z. [Relationship between quality of sleep and quality of life in dialysis patients of dialysis centers in Chaharmahal and Bakhtiari, Iran]. Research of health sciences journal. 2012; 8(3): 515-21. Persian

3- $\quad$ Abbaszadeh A, Javanbakhtian R, Salehee S, Motvaseliyan M. [Comparative assessment of quality of life in hemodialysis and kidney transplant patients]. SSU_Journals. 2010;18(5):461-8. Persian

4- $\quad$ Taheri N, Kamangar S, Cheraghian B, Mousavi Szo, Solaimanzadeh M. [Life quality of hemodialysis patients]. Journal of Knowledge \& Health 2013;8(3):119-24. Persian

5- Narimani M, RafighIrani S. [Relationship of coping methods and Psychiatric health in hemodialysis patients]. Journal of Psychiatric health principles. 2008; 10(2): 117-22. Persian

6- $\quad$ Amini Z, Fazel A, Zeraati A, Esmaeili H. [The effect of care plan based on the roy adaptation model on activities of daily living of hemodialysis patients]. Journal of North Khorasan University of Medical Sciences, 2012; 4(2): 145-53. Persian

7- $\quad$ Weisbord SD, Fried LF, Arnold RM, Fine MJ, Levenson DJ, Peterson RA, et al. Prevalence, severity, and importance of physical and emotional symptoms in chronic hemodialysis patients. $J \mathrm{Am}$ Soc Nephrol. 2005;16(8):2487-94.

8- Yong D, Kwok A, Wong D, Suen M, Chen W, Tse D. Symptom burden and quality of life in end-stage renal disease: a study of 179 patients on dialysis and palliative care. Palliat Med. 2009;23(2):111-9.

9- $\quad$ Sajjadi M, Akbari A, Kianmehr M, Atarodi A. [The relationship between self-care and depression in patients undergoing hemodialysis]. The Horizon of Medical Sciences. 2008;14(1):13-7. Persian

10- Denzin NK, Lincoln YS. The Sage handbook of qualitative research: Sage; $4^{\text {th }}$ ed. 2011.

11- Polit DF, Beck CT. Nursing research: Generating and assessing evidence for nursing practice: $9^{\text {th }}$ ed. 2012. Lippincott Williams \& Wilkins.

12- $\quad$ Elo S, Kyngäs H. The qualitative content analysis process. J Adv Nurs. 2008;62(1):107-15.

13- Mayring P. Qualitative content analysis: theoretical foundation, basic procedures and software solution. Klagenfurt, 2014. URN: http://nbn-resolving.de/urn:nbn:de:0168-ssoar-395173

14- $\quad$ Ghadami A, Memarian R, Mohamadi E. [A qualitative study of hemodialysis as a grueling experience versus kidney transplantation as a rebirth]. Arak Medical University Journal, 2012. 15 (463): 48-62. Persian

15- Aghakhani N, Nazari R, Sharif Nia H, Nahrir B. [A comparative study of quality of life (qol) among patients with haemodialysis and peritoneal dialysis]. J GorganBouyeh Fac Nurs Midwifery. 2011;8(2):35-42. Persian

16- $\quad$ Ferreira RC, Silva Filho CRd. Quality of life of chronic renal patients on hemodialysis in Marília, SP, Brazil. Jornal brasileiro de nefrologia. 2011;33(2):129-35.

17- $\quad$ Imani E, Imani A. [The effect of foot massage on sleeping in hemodialysis patients]. Shahid Sadughi J. 2009;17(2):76-82. Persian

18- Hassani P, Otaghi M, Zagheri Tafreshi M. [Nikhbakht Nasrabadi AR. The transition to hemodialysis: qualitative studi]. Iranian Journal of Critical Care Nursing. 2012. 6(2):73-80. Persian

19- $\quad$ Mirbagher AN, Aghajani M, Morsaee F, Zabolian Z. [The Relationship between Hope and Depression-Anxiety in Patients Undergoing Hemodialysis]. Journal of Health and Care. 2016.18(1): 55-62. Persian

20- Raisi F, Nasehi A, Ekhtiari M. [The prevalence of depression in hemodialysis patients in Emam Khomeyni Hospital]. Cognetive Sci J. 2005;2:55-9. Persian

21- Asgari MR, Mohammadi E, Fallahi Khoshknab M, Tamadon MR. [Hemodialysis patients' perception from nurses' role in their adjustment with hemodialysis: A qualitative study]. Koomesh. 2011:385-97. Persian

22- Parsons TL, Toffelmire EB, King-VanVlack CE. Exercise training during hemodialysis improves dialysis efficacy and physical performance. Arch Phys Med Rehabil. 2006;87(5):680-7. 
23- Chojak K, Smolenski O, Milkowski A, Pitrowski W. The effects of 6-month physical training conducted during hemodialysis in ESRD patients. Med Rehabil. 2006;10(2):25-41.

24- Riahi Z, Esfarjani F, Marandi S, Kalani N. [The effect of intradialytic exercise training on the quality of life and fatigue in hemodialysis patients]. J Res Rehabil Sci. 2012;8(2):219-27. Persian

25- Al-Arabi S. Quality of life: subjective descriptions of challenges to patients with end stage renal disease. Nephrol Nurs J. 2006;33(3):285-98.

26- Rambod M, Rafii F, Hosseini F. [Quality of life in patients with end stage renal disease]. Journal of hayat. 2008;14(2):51-61. Persian

27- Ahmadvand A. [Effect of cognitive-behavioral group therapy on anxiety and depression hemodialysis patients in Kashan, Iran]. Qom University of Medical Sciences Journal. 2012;6(1): 35-9. Persian

28- BasampoorShiva., AsadiNoghabi Ahmad Ali., ZolfaghariMitra. Critical nursing care, ICU, CCU, Dialysis, $3^{\text {th }}$ ed, Thehran:Salemi publication, 2008. 


\title{
Perception of Illness in Patients Undergoing Hemodialysis: A Qualitative Study
}

\author{
Saeedi M. MS. ${ }^{1}$ \\ *Ghafarzadeghan R. MS. ${ }^{2}$ \\ Hekmatpou D. $\mathrm{PhD}^{3}$
}

\begin{abstract}
Background \& Aim: End- stage renal disease and hemodialysis dependence affect all aspect of patients' life and bring them different experiences. The aim of the present study is to explore the perception of illness in hemodialysis patients.

Materials \& Methods: This qualitative research was conducted, using inductive and conventional qualitative content analysis approach. Data were collected through semi-structured interview with 21 patients in the hemodialysis ward of Valiasr hospital, selected by purposeful sampling. All interviews were performed by one researcher within two months. Each interview lasted 40 minutes. The data were analyzed along with data collection process.

Results: During the data analysis process, five categories were extracted, i.e. disabling complications of disease, hopelessness, life dissatisfaction, the sense of dependence, and turbulent thoughts. "Helplessness caused by the disease" was emerged as the theme of this research.

Conclusion: The findings of this research showed that hemodialysis patients often encounter unpleasant experiences, leading to helplessness and a decreased quality and hope of life. Therefore, the physicians and nurses of hemodialysis ward should pay more attention to the problems of these patients.
\end{abstract}

Keywords: End Stage Renal Disease, Perception, Qualitative Research

Received: 23 Jul 2017

Accepted: 21 Oct 2017

\footnotetext{
1. Instructor, Department of Nursing, Faculty of Nursing \& Midwifery, Saveh University of Medical Sciences, Saveh, Iran.

2. Instructor, Department of Nursing, Faculty of Nursing \& Midwifery, Khomein University of Medical Sciences,

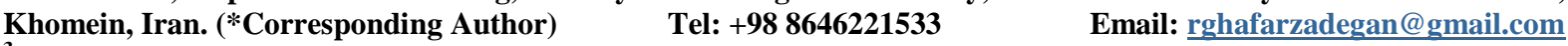
${ }^{3}$. Associate Professor. Department of Nursing, Faculty of Nursing \& Midwifery, Arak University of Medical Sciences, Arak, Iran.
} 